\title{
Correlation between Weather Parameters and Sunflower Powdery Mildew Caused by Erysiphe cichoracearum DC
}

\author{
A. Bheemaraya*, M.M. Jamadar and Shalini Huilgol
}

Department of Plant Pathology, College of Agriculture, Bijapur, University of Agricultural Sciences, Dharwad - 580 005, Karnataka, India

*Corresponding author

\section{A B S T R A C T}

\begin{tabular}{|l|}
\hline Ke y w o r d s \\
$\begin{array}{l}\text { Dates of sowing, Disease } \\
\text { severity, Powdery mildew } \\
\text { (Erysiphe } \\
\text { cichoracearum), Weather } \\
\text { parameters }\end{array}$ \\
\hline Article Info \\
\hline $\begin{array}{l}\text { Accepted: } \\
\text { 24 August 2018 } \\
\text { Available Online: } \\
\text { 10 September } 2018\end{array}$ \\
\hline
\end{tabular}

Sunflower (Helianthus annuus L.) is native of southern USA and Mexico. Among the different diseases on sunflower; the powdery mildew caused by Erysiphe cichoracearum DC has been serious diseases in northern Karnataka causes sever losses in present climate change situation. Hence the experiment is carried out in 2013-14 at College of Agriculture, Bijapur, to know the effect of weather parameters in seven dates of sowing on sunflower powdery mildew. Sunflower crop sown in I fortnight of October recorded maximum disease severity (39.64\%) followed by II fortnight of September (74.07\%) and the least $(8.80 \%)$ recorded in II fortnight of July sown crop. Maximum and minimum temperature, maximum and minimum vapour pressure and both morning and evening relative humidity had significant negative correlations with disease in irrespective of different crop growth periods (40, 60, 80 and 100 days after sowing). Marked significant positive correlation of cloud cover was noticed with disease intensity at 40, 60 and 80 days crop growth stages. However, rainfall was negative but non-significant in its relationship with powdery mildew infection.

\section{Introduction}

Sunflower (Helianthus annuus L.) is native of southern USA and Mexico. It is a rich source of edible oil (40-52\%) having anticholesterol properties (Joksimovic et al., 2006). India is the third largest producer of the oilseeds, the country is facing an acute shortage of edible oil. The per capita annual consumption of vegetable oil is only $9 \mathrm{~kg}$ in India as against $22 \mathrm{~kg}$ in developed countries. Presently in India sunflower is cultivated over an area of 1.72 mha with a production of $0.50 \mathrm{MT}$ and productivity of $692 \mathrm{~kg} / \mathrm{ha}$ (Anon., 2013). The cultivated sunflower is largely confined to southern parts of the country comprising the states like Andhra Pradesh, Karnataka, Maharashtra and Tamil Nadu. Karnataka stands first among these southern states accounting for an area of 0.38 mha with a production of $0.19 \mathrm{MT}$ and productivity of $503 \mathrm{~kg} / \mathrm{ha}$; thus contributing for a major share $(42.83 \%)$ in the country's sunflower production (Anon., 2012).

The lower levels of sunflower yields are mainly due to several biotic and abiotic factors. Among these, susceptibility to disease 
is considered to be one of the major constraints. Kolte (1985) observed that the crop suffers from various diseases incited by fungi, bacteria, viral and phytoplasma. Among the fungal disease of sunflower Alternaria leaf spot (Alternaria helianthi), rust (Puccinia helianthi), downy mildew (Plasmapara halstedii Farl.), are important. Recently, powdery mildew and necrosis disease have become most important limiting factors of cultivation in sunflower.

Although some work has been done on this disease, yet there are many obscure aspects of the disease which needs immediate attention. The loss due to powdery mildew is proportionate to the disease intensity and varies considerably depending on the stage of the plant growth at which disease occurs. Powdery mildew like other fungal diseases is influenced by weather factors. Generally, it prevails in dry conditions, which is commonly experienced in the northern dry zone of Karnataka therefore influence of weather parameters such as temperature, relative humidity (RH) and other microclimatic factors is very important to develop forewarning system in this disease. keeping these facts, the present investigation was carried out.

\section{Materials and Methods}

The experiment was conducted in research fields of College of Agriculture, Bijapur in a Randomized Complete Block Design (RCBD) with three replications and seven dates of sowings (I Fortnight of July, II Fortnight of July, I Fortnight of August, II Fortnight of August, I Fortnight of September, II Fortnight of September and I Fortnight of October). Individual plot size was $5 \times 4 \mathrm{~m}^{2}$. Sunflower seeds were sown at $60 \mathrm{~cm}$ spacing between rows and $30 \mathrm{~cm}$ between plants. The first date of sowing was imposed by sowing seeds of highly susceptible hybrid 'KBSH-44' in 1st fortnight of July and subsequent sowings were done at an interval of 15 days till the last sowing date i.e. $1^{\text {st }}$ fortnight of October.

Totally seven different date of sowings were imposed in the experiment. The cultural practices like intercultivation and weeding were attended as required. General sprays of insecticides were given whenever necessary to avoid damage from pests. The crop was raised as per UAS Package of Practices for sunflower cultivation except for management of powdery mildew. The severity of powdery mildew was recorded periodically at 20 days interval after the disease appearance on five randomly selected plants per plot using 0-5 disease rating scale, and Per cent Disease Index (PDI) were worked out. The weather data (experimental period) of RARS, Bijapur was collected from meteorological unit and used for correlation with the powdery mildew severity.

Further, per cent disease index (PDI) was calculated by using following formula proposed by Wheeler (1969).

Per cent disease index $=\frac{\text { Sum of the individual disease ratings }}{\text { Number of leaves assesed XMaximum grade }} X 100$

\section{Results and Discussion}

\section{Effect of time of planting on powdery mildew development on sunflower}

The results (Table 1) on the different dates of sowing of sunflower on powdery mildew severity revealed that sowing of crop in the II fortnight (FN) of July recorded the minimum powdery mildew infection (8.80\%) followed by crop sown in I FN of August (8.82\%) as against the crop sown in I FN of October (39.64\%) and II FN of September (27.18\%). It was also observed that the disease progressed linearly from initial disease incidence $(4.08 \%)$ recorded at 40DAS and reached the highest disease intensity (37.92\%) at 100 DAS. 
However there was exception to this disease progress in the early sowing dates that indicated the decline in the disease development at 80 DAS as evident from July I FN (7.70\%) and II FN (5.05\%) as well as sowing in the August I FN (2.76\%) sowing recorded low powdery mildew after fairly higher disease intensity at 60 DAS. At 100 DAS the disease intensity again increased indicating the definite as well as significant meteorological interventions.

The maximum disease severity was noticed in I fortnight of October sown crop with initial PDI (16.40\%) and maximum PDI (71.48\%) at harvest, followed by II fortnight of September sown crop with initial PDI (4.04\%) and maximum PDI (60.35\%) at harvest. The least severity was observed in the II fortnight of July sown crop with initial PDI $(0.66 \%)$ and maximum PDI (19.52\%) at harvest.

Sowing with 20 days interval starting from 1st August, the per cent severity of the disease was low in first sown crop; but it increased in second sown crop and again subsequently reduced in third sown crop (Sivaprakasam et al., 1981).

In all the three dates of sowings the onset of disease was noticed on $44^{\text {th }}$ week and reached peak at harvesting of all sowing dates. The second sowing date (7-9-2009), recorded maximum per cent disease index $(85.18 \%$ PDI) followed by first sowing date $(74.07 \%$ PDI) and least in third sowing date $(44.06 \%$ PDI) (Sanjivareddi, 2012).

\section{Correlation of weather parameters with sunflower powdery mildew}

The results (Table 2) on correlations of antecedent weather parameters at (20-1 DBO i.e. days before observation) with powdery mildew incidence at 40 DAS crop growth stage revealed highly significant and negative correlation of minimum temperature (-0.99) maximum and minimum vapour pressure (-0.9 and -0.89$)$ and morning relative humidity (0.85 ), whereas significant and positive relationship (0.83) was observed with cloud cover. The similar trend was also noticed with above weather variables at 5-1 DBO and 2016 DBO except cloud cover. The rainfall did not have any significant relationship with powdery mildew intensity at this growth stage.

At 60 DAS there were no significant correlations with any of the weather parameters except morning relative humidity $(-0.75)$ and cloud cover (0.81) at 20-16 DBO antecedent weather conditions.

At 80 DAS highly significant relationship with powdery mildew was noticed with respect to minimum temperature (-0.94), maximum vapour pressure (-0.90), minimum vapour pressure (-0.87) while significant and negative relationship of morning and evening relative humidity (-0.83 each) was observed at 20-1 DBO. In case of cloud cover significant positive weather relations $(0.77)$ with powdery mildew intensity was noticed and at 5-1 DBO highly significant correlations were observed in case of minimum temperature (-0.98) and maximum vapour pressure (-0.95) as well as significant relationship with cloud cover (0.83). In this case also rainfall had no significant influence on the powdery mildew intensity with any of the DBOs.

At 100 DAS there were no significant weather parameters influencing the powdery mildew were observed except at 20-16 DBO, where minimum temperature (-0.77), maximum and minimum vapour pressure $(-0.76,-0.82$, respectively) as well as evening relative humidity (-0.78) were observed to have significant negative relationship.

Here too rainfall did not influence the powdery mildew severity. 
The weather data (experimental period) of RARS, Bijapur

\begin{tabular}{|c|l|}
\hline Disease rating & Percent incidence/ leaf infection \\
\hline 0 & No disease \\
\hline 1 & $1-10 \%$ infection \\
\hline 2 & $11-25 \%$ infection \\
\hline 3 & $26-50 \%$ infection \\
\hline 4 & $51-75 \%$ infection \\
\hline 5 & $>75 \%$ infection \\
\hline
\end{tabular}

Table.1 Effect of dates of sowing of sunflower on powdery mildew severity and yield

\begin{tabular}{|l|c|c|c|c|c|}
\hline \multicolumn{7}{|c|}{ Treatments } & \multicolumn{5}{|c|}{ Per cent Disease Index (PDI) } \\
(q/ha) \\
\hline
\end{tabular}

* Figures in the parentheses are arc sine transformed value 
Table. 2 Correlation between weather parameters and sunflower powdery mildew (Erysiphe cichoracearum DC)

\begin{tabular}{|c|c|c|c|c|}
\hline \multicolumn{5}{|c|}{40 DAS crop growth stage } \\
\hline \multicolumn{2}{|c|}{ Weather parameters } & 5-1 DBO & 20-16 DBO & 20-1 DBO \\
\hline \multirow[t]{2}{*}{ Temperature $\left({ }^{\circ} \mathrm{C}\right)$} & Max. & -0.72 & -0.05 & -0.74 \\
\hline & Min. & $-0.98 * *$ & $-0.96 * *$ & $-0.99 * *$ \\
\hline \multirow[t]{2}{*}{ Vapour pressure (\%) } & Max. & $-0.97 * *$ & $-078 *$ & $-0.97 * *$ \\
\hline & Min. & $-0.82 *$ & -0.71 & $-0.89 * *$ \\
\hline \multirow[t]{2}{*}{ Relative humidity (\%) } & Morn. & $-0.87 * *$ & -0.57 & $-0.85^{*}$ \\
\hline & Even. & -0.47 & -0.44 & -0.73 \\
\hline Cloud cover & & 0.38 & 0.73 & $0.83 *$ \\
\hline Rainfall (mm) & & -0.39 & -0.30 & -0.59 \\
\hline \multicolumn{5}{|c|}{60 DAS crop growth stage } \\
\hline \multicolumn{2}{|c|}{ Weather parameters } & 5-1 DBO & 20-16 DBO & 20-1 DBO \\
\hline \multirow{2}{*}{ Temperature $\left({ }^{\circ} \mathrm{C}\right)$} & Max. & -0.61 & -0.2 & -0.31 \\
\hline & Min. & -0.61 & -0.63 & -0.45 \\
\hline \multirow[t]{2}{*}{ Vapour pressure (\%) } & Max. & -0.45 & -0.70 & -0.39 \\
\hline & Min. & -0.35 & -0.74 & -0.39 \\
\hline \multirow[t]{2}{*}{ Relative humidity (\%) } & Morn. & 0.08 & $-0.75^{*}$ & -0.40 \\
\hline & Even. & -0.20 & -0.46 & -0.28 \\
\hline Cloud cover & & 0.02 & $0.81 *$ & 0.34 \\
\hline Rainfall (mm) & & -0.19 & 0.22 & -0.15 \\
\hline \multicolumn{5}{|c|}{80 DAS crop growth stage } \\
\hline \multicolumn{2}{|c|}{ Weather parameters } & 5-1 DBO & 20-16 DBO & 20-1 DBO \\
\hline \multirow[t]{2}{*}{ Temperature $\left({ }^{\circ} \mathrm{C}\right)$} & Max. & -0.58 & -0.29 & $-0.79 *$ \\
\hline & Min. & $-0.98 * *$ & $-0.76^{*}$ & $-0.94 * *$ \\
\hline \multirow[t]{2}{*}{ Vapour pressure (\%) } & Max. & $-0.95 * *$ & -0.74 & $-0.90 * *$ \\
\hline & Min. & -0.68 & -0.70 & $-0.87 * *$ \\
\hline \multirow[t]{2}{*}{ Relative humidity (\%) } & Morn. & -0.64 & $-0.81 *$ & $-0.83^{*}$ \\
\hline & Even. & -0.55 & -0.60 & $-0.82 *$ \\
\hline Cloud cover & & $0.83 *$ & 0.42 & 0.77 \\
\hline Rainfall (mm) & & -0.59 & -0.53 & -0.59 \\
\hline \multicolumn{5}{|c|}{100 DAS crop growth stage } \\
\hline \multicolumn{2}{|c|}{ Weather parameters } & 5-1 DBO & 20-16 DBO & 20-1 DBO \\
\hline \multirow[t]{2}{*}{ Temperature $\left({ }^{\circ} \mathrm{C}\right)$} & Max. & 0.23 & -0.54 & -0.21 \\
\hline & Min. & 0.00 & $-0.77 *$ & -0.53 \\
\hline \multirow[t]{2}{*}{ Vapour pressure $(\%)$} & Max. & -0.16 & $-0.76^{*}$ & -0.63 \\
\hline & Min. & -0.26 & $-0.82 *$ & -0.57 \\
\hline \multirow[t]{2}{*}{ Relative humidity (\%) } & Morn. & -0.33 & -0.60 & -0.65 \\
\hline & Even. & -0.32 & $-0.78 *$ & -0.60 \\
\hline Cloud cover & & 0.19 & 0.57 & 0.74 \\
\hline Rainfall (mm) & & -0.25 & -0.42 & -0.49 \\
\hline
\end{tabular}

DBO - Day Before Observation

* Significant at 5\%,** Significant at $1 \%$ 
The role of weather parameters like temperature, relative humidity $(\mathrm{RH})$, vapour pressure, cloud cover and rainfall on powdery mildew development in sunflower studied under field conditions during late kharif and rabi 2013, revealed varied disease severity in different sowing dates from I fortnight of July to I fortnight of October at 40, 60, 80 and 100 DAS.

In most of the sunflower sowing dates, it was generally observed that minimum and maximum temperature, minimum and maximum vapour pressure, morning and evening relative humidity were highly significant parameters and had negative impact on disease development whereas cloud cover had positive impact on powdery mildew development. it was also observed that rainfall in most cases did not have significant effect on the disease except for sowing of sunflower in I FN of August (-0.84 at 20-1 DBO and -0.93 at $20-16$ DBO), II FN of August (-0.79 at 20-1 DBO and -0.78 at 5-1 DBO) and I FN September (-0.85 at 5-1 DBO). Thus it underlined the significance of rainfall on the buildup/disease development of powdery mildew during August and September months.

Unlike most other fungal diseases, which are favoured by moist conditions powdery mildew grows well in dry climate. The disease develops much more abundantly in shade or diffused light than in bright light thus warm and cloudy weather provides ideal conditions for the spread of the fungus. The optimum temperature for growth is between 75 to $95^{\circ} \mathrm{F}$ (Butler and Jones, 1949). The fungus ceases its growth below $10^{\circ} \mathrm{C}$ above $37.7^{0} \mathrm{C}$ heavy rain or hot dry weather is unfavourable for the growth of the fungus. Low, diffuse light favours development of powdery mildew however, bright sunlight inhibits conidial germination. It was observed that conidial germination was $47 \%$ in diffused light but only $16 \%$ in bright sunlight (Aurel, 1974). Kareppa et al., (2004) working on epidemiological aspects of powdery mildew on grapes at Grapes Research Centre, Pimpalgaon, Baswant (Dist. Nasik) observed that, the maximum and minimum temperatures were significantly but negatively correlated with the intensity of powdery mildew. It indicated that as the temperature (maximum, minimum) decreased the intensity of powdery mildew increased. The humidity (evening) and rainfall were also nonsignificantly negatively correlated whereas humidity (morning) was non-significantly positively correlated. Multiple linear regression analysis between spores load of Leveillula taurica and weather parameters indicated a negative correlation between allweather parameters, viz. maximum and minimum temperature, morning and evening relative humidity and rainfall during 2004 but significant correlation was observed with minimum temperature and evening relative humidity, except maximum temperature all other weather parameters showed significant negative correlation (Ashtaputre, 2006).

\section{References}

Anonymous, 2012, Directorate of economics and statistics, Department of Agriculture and Co-operation, New Delhi, pp. 107.

Anonymous, 2013, Food and agricultural organisation statics. http://faostat3.fao. org/faostatgateway/go/to/download/Q/Q $\mathrm{C} / \mathrm{E}$.

Ashtaputre, S. A., 2006, Studies on loss assessment, epidemiology and management of powdery mildew of chilli caused by Leveillula taurica (Lev.) Arn. Ph. D Thesis, Univ. Agric. Sci., Dharwad, Karnataka (India), pp. 79-81.

Aurel, T., 1974, Ceretari privind biologia cinpercii Uncinula necator (Schw). 
Burr. Care provoaca fairnarea vitei de vie simijloacele de combaterre in conditiile podgorei Dealul mare. Ph.D. Thesis, Institutul Agronomic. Bucuresti, Romania.

Butler, E. J. and Jones, S.G., 1949, Plant Pathology, Macmillian and Co. London.

Joksimovic, J., Atlagic Jovanka, Marinkovic, R. and Jovanovi, D., 2006, Genetic control of oleic and linoleic acid contents in sunflower. Helia, 29(44): 33-40.

Kareppa, S.M., Ghure, T.K. And Yadav, D.B., 2004, Epidemiological aspects of powdery mildew on grape $J$. Maharashtra Agric Univ., 29(1): 103 104.
Kolte, S.J., 1985, Diseases of Annual Edible Oilseed Crops III. CRC Press, Florida, pp. 9-96.

Sanjivareddi, Y.B. 2012 Investigations on powdery mildew (Erysiphe cichoracearum DC. f.sp. helianthi Jacz.) of sunflower in northern dry zone of Karnataka M.Sc. Thesis, Univ. Agric. Sci., Dharwad, Karnataka (India).

Sivapraakasam, K., Marimuthu, T., Radhakrishan, T. and Vairavan, K., 1981, Influence of dates of sowing and spacing on the incidence of powdery mildew of green gram and black gram. Madras Agric. J., 68: 65-67.

Wheeler, B.E.J., 1969, An Introduction to Plant Disease. John Wiley \& Sons Ltd., London, p. 301.

\section{How to cite this article:}

Bheemaraya, A., M.M. Jamadar and Shalini Huilgol. 2018. Correlation between Weather Parameters and Sunflower Powdery Mildew Caused by Erysiphe cichoracearum DC. Int.J.Curr.Microbiol.App.Sci. 7(09): 3503-3509. doi: https://doi.org/10.20546/ijcmas.2018.709.434 